\title{
Remotely Piloted Aircraft: Analysis of the Deployment in Aeronautical Accident Investigation Bureau
}

\author{
Humberto Dorneles Santa Maria ${ }^{1}$ (D), Rodrigo Franklin Frogeri2,* (D), Fabrício Pelloso Piurcosky² (D, \\ Liz Áurea Prado² (1)
}

1. Academia da Força Aérea - Pirassununga, São Paulo (SP), Brazil. 2. Grupo Educacional UNIS - Departamento de Pesquisa Varginha, Minas Gerais (MG), Brazil.

*Correspondence author: rodrigo.frogeri@professor.unis.edu.br

\begin{abstract}
This study analyzed Remotely Piloted Aircraft System (RPAS) deployment in the Regional Services of Aeronautical Accidents Investigation and Prevention (SERIPA - Brazil) as a support tool to investigate aviation accidents. Such review is justified by the acquisition and use of this equipment and new technology by investigators since 2017. Research aim was to analyze the perception of SERIPA investigators regarding the usefulness and ease of use of the RPAS equipment. We applied an adaptation of the Theoretical Model of Technology. Methodologically, the study was characterized as exploratory and carried out through an inductive logic and qualitative approach. A case study has been done with 14 investigators belonging to six Brazilian SERIPA units. In conclusion, the respondents deem the RPAS to be useful for aircraft accident investigation, and the equipment is of easy use. RPAS was observed as a tool capable of replacing manned aircraft in some crash sites. The external variable, i.e. crash site characteristics, emerged as a factor that influences the use of RPAS, as well as the transport of RPAS in commercial aircraft.
\end{abstract}

Keywords: Airplane accident; Investigation; Technology Acceptance Model; Remotely piloted aircraft system; RPAS.

\section{INTRODUCTION}

Towards the end of World War II, the international aviation community agreed on the need to develop common rules and standards to regulate the fast growing of civil aviation (ANAC 2016). Thus, the International Civil Aviation Organization (ICAO) enacted the International Civil Aviation Convention in 1944 in order to develop aviation safely and systematically (Brasil 1946). Among the annexes to the Chicago Convention, Annex 13 recommended that Member States should adopt procedures to carry out the investigation of aviation accidents with the exclusive goal of preventing new occurrences.

In Brazil, the Center of Research and Prevention of Aeronautical Accidents (CENIPA) is the Agency of Air Force Command responsible for investigating activities of aviation occurrences in civil aviation and the Brazilian air force. The Military Organization (MO) has seven regional offices, with headquarters in the cities of Belém - state of Pará (PA), Recife - state of Pernambuco (PE), Rio de Janeiro - state of Rio de Janeiro (RJ), São Paulo (SP) - state of São Paulo, Canoas - state of Rio Grande do Sul (RS), Brasília state of Distrito Federal (DF), and Manaus - state of Amazonas (AM).

Received: Apr. 29, 2019 | Accepted: Aug. 17, 2020

Peer Review History: Double Blind Peer Review.

Section Editor: Marina Efthymiou

This is an open access article distributed under the terms of the Creative Commons license. 
In order to improve the civil aviation investigation activity process, the CENIPA acquired, in March 2017, a Remotely Piloted Aircraft System (RPAS), popularly known as drone, for each regional office, as well as three units for the MO itself. The equipment, which is deployed as a support tool during an aircraft accident investigation, is used for the photographic record of wreckage and crash site, especially allowing for a broader view of the site. RPAS can assist investigators due to its ability to record images from a higher height than those obtained in the conventional way, at ground level.

For a week, one investigator from each Brazilian Regional Investigation and Prevention of Aeronautical Accidents (SERIPA) received a training to operate a RPAS in the CENIPA. After this period, the trained individuals were tasked to propagate the knowledge received in their respective units. One year after the acquisition of the equipment (RPAS), no air accident investigations were conducted using a RPAS. Such a claim is because one of the authors of this study belongs to SERIPA 2 and has followed the investigations conducted throughout the Brazilian national territory in recent years. Until the conclusion of this research there were no official records in CENIPA of air accident investigations that made use of an RPAS. Until the completion of this research, the investigators' perception of the usefulness of RPAS as well as its level of complexity for the operation or factors that could prevent the use of the aircraft had not been observed. Based on the low frequency of RPAS deployment during accident investigation, two assumptions were considered: P1 - accident investigators consider RPAS a useless tool, as photographic records can also be obtained through camera or cell phone use; P2 - accident investigators consider RPAS a complex and fragile device and therefore avoid its use.

This study is necessary due to the high value invested in the equipment acquisition, in the face of low use of the tool. RPAS of the $3 \mathrm{DR} \mathrm{SOLO}{ }^{\odot}$ model was purchased from the manufacturer 3DR, together with tablets for the interface and digital machines GO PRO HERO $4^{\odot}$. With the purchase of the equipment, the CENIPA envisioned an improvement in the process of collection and analysis of information from the places of aviation accidents. RPAS can improve the view of a wreckage under a new perspective. The investigator in charge would sophisticate the decision-making process, modernize research techniques of aviation accidents, reduce operating costs, and maximize the work efficiency of the Committee of Investigation during the investigative process of the SIPAER - Brazilian Aeronautical Accident Investigation and Prevention System (Brasil 2016). Faced with a scenario of aircraft accident investigation guided by RPAS as a supporting tool for obtaining images, we have defined the research question: considering RPAS a new technology in MO, do the operators of SERIPA deem it a usefulness and easy-used tool during an aircraft accident investigation? The general aim of the research was to analyze the perception of SERIPA investigators regarding the usefulness and ease of use of the RPAS equipment.

We adopted a theoretical model adaptation of the technology acceptance model (TAM) in order to achieve the proposed objective. The specific objectives include: O1 - check the previous experience of investigators with RPAS; O2 - find out the possible use of RPAS simulator for familiarization of investigators with the equipment; O3 - identify the investigators' knowledge about RPAS use laws, specifically, the ICA 100-40 (RPAS and access to the Brazilian airspace) and RBAC 94E (General Requirements for Unmanned Aircraft to Civilian Use).

The research purpose was achieved through a qualitative approach developed by the case study method with application of semistructured interviews to 14 aircraft accident investigators (officers and NCOs - non-commissioned officer), operators of RPAS, in Brazil.

\section{THEORETICAL BACKGROUND}

The theoretical framework of this study is divided into three parts. The first one is a literature research of studies related to the use of RPAS. Secondly, the theoretical fundamentals of the TAM are presented. Finally, a comparative analysis of technology adoption models are discussed.

\section{Previous Research - Remotely Piloted Aircraft System Acceptance in Society}

MacSween-George (2003), in a study conducted in the United States of America on the social acceptance of RPAS as a means of transportation of cargo or passengers, identified that the more information about the risks and potential benefits are transmitted to users, the greater the acceptance of Remotely Piloted Aircraft. 
Lidynia, et al. (2016) researched 200 people, laypeople and active RPAS users, on the acceptance and perception of barriers to using RPAS. The study showed that the type of RPAS user (layperson or active users) strongly influences both the acceptance and perception of barriers to using the equipment. According to study conclusions, laypeople were very afraid of their privacy violation, while active users of RPAS saw more risks in possible accidents.

Clothier et al. (2015) investigated the perception of operation risks between unmanned aerial vehicles and conventional vehicles piloted in Australia. The authors concluded that the risks do not differ regardless of the air vehicle used. For Rangel (2018), the training of investigators of RPAS, as well as the performance of these according to the proposed regulations by the competent organs, are fundamental factors for safe operations. Nunes (2017) noted that the RPAS used in the Fire Department of the State of Santa Catarina/Brazil is useful to show places of difficult access, allowing a better evaluation of the victims of accidents and contributing to corporate decision-making in support of disaster relief.

Constantinescu and Nedelcut (2011) and Alfaro (2015) attested that the RPAS "are easy to carry and can observe the area using a digital camera with heat sensor." The observation takes into consideration their use in support of police operations in Romania.

Gomez et al. (2017) comment that access to crash sites becomes a difficult task in Colombia due to high-ground characteristics. The Grupo de Investigación de Accidentes e Incidentes de Aviación (GRIAA), which is subordinate to the Department of Transportation, depends on the availability of Colombian air force helicopters for aerial imagery. Even with the use of these aircraft, not always the angle and the detailing of the photographs are satisfactory. In this context, Gomez et al. (2017) discussed the benefits of RPAS to the investigation of aviation accidents. RPAS could allow an inspection at the crash site, a search for wreckage, an estimated height of trees and objects, secure access to the crash site (mitigation of risks investigators), and a preview/reconstruction of the flight trajectory. In their evaluations, Gomez et al. (2017) concluded that the use of RPAS imaging, complemented by photogrammetry software, provides a useful tool for the investigation of aircraft accidents at a much lower cost than hiring a commercial helicopter or using laser scanning equipment.

Hawkins (2016) discussed the use of RPAS in the Air Accidents Investigation Branch (AAIB) and has registered 23 operations with the device for two years. The author points out that the equipment costs significantly less than a manned aircraft and can fly in conditions of low visibility and low clouds - these conditions would prevent the operation of a plane or helicopter. In addition, the RPAS is ensured to fly around the trees and debris to get close-up images, without modifying them with the rotor's downs hash (an aerodynamic effect that produces support when close to the ground in rotary wing aircraft, due to the breath of the main rotor).

According to Comitre and Balcewicz (2018), the largest e-commerce company of Iceland (AHA) reduced the time to transport their products in $84 \%$ by using the RPAS compared to a car in heavy traffic. In addition, there is a $60 \%$ reduction in the costs of delivery if compared to the conventional alternatives (terrestrial and marine). Comitre and Balcewicz (2018) proposed the use of RPAS for pizza deliveries, redefining the food delivery logistics.

The use of RPAS in the most different areas has considerable benefits, but its adoption must come together with technical and planning of social/cultural changes (Comitre and Balcewicz 2018).

\section{Technology Acceptance Model}

The TAM has been widely used to understand behaviours contributing to the acceptance and use of computer technology and information systems (Kurtz et al. 2015). TAM is originated from the evolution of Theory of Reasoned Action (TRA), proposed by Fishbein and Ajzen (1975), in which the action of individuals (behavioral intention) is influenced by beliefs, attitudes, and subjective norms. Based on the TRA model, Davis (1989) proposed a new theory to create a model information technology acceptance, adding the perception of usefulness and ease of use as prerequisites for the individual's behavior.

Davis (1989) model uses two primary factors (constructs) to predict acceptance user of technology: perceived usefulness (PU), which is defined as the degree to which users actually believes that technology will increase the performance of their work; and perceived ease of use (PEOU), which can be explained as the degree to which the user finds easy-to-use technology, as well as the benefits of this technology outweigh the effort to employ it.

Initially developed to evaluate the use of a word processor in work situation (Davis 1989), the TAM, after the suggestion for including external variables (Davis et al. 1989), was adapted to assess the intent and use of various technologies (Kurtz et al. 2015). 
According to Davis et al. (1989), external variables are any factor that influences the behavior - only indirectly. Thus, features and settings of the systems (design), characteristics of the users (including cognitive style and other personality variables), task characteristics, nature of development, implementation of processes, political influence, organizational structure, and other situations could be classified in this category.

According to Davis (1989), the individuals tend to use a technology to improve their performance at work (Perceived UtilityPerceived Usefulness). However, even if that person understands that a particular technology is useful, this may be affected if it is very complex, so that the effort does not compensate the practice (PEOU). Davis (1989) developed a procedure to create new multi-item scales, with high reliability and validity. The conceptual definitions of perceived usefulness and PEOU were used to generate 14 items (variables) candidates for each construct.

According to the TAM, "psychometricians emphasize that the validity of a measurement scale is constructed from the beginning." Nunnally (1978 apud Davis, 1989) points out: "rather than test the validity of the measures after having been built, it must ensure the validity of the project and construction procedures." Thus, pre-test interviews were carried out to evaluate the semantic content of the items. The elements that best fit the definitions of constructs (PU and PEOU) were kept, generating ten items for each construct, as Table 1 .

Table 1. Selected variables of the constructs

\begin{tabular}{cc}
\hline Perceived usefulness & Perceived ease of use \\
\hline Works faster & Easy to learn \\
\hline Productivity increase & Controllable \\
\hline Improves the work performance & Easy to use \\
\hline Effectiveness & Rigid and inflexible \\
\hline Provides a job easier & Easy to remember (functions) \\
\hline Utility & Requires mental effort \\
\hline Quality of work & Nuisance \\
\hline Control over the work & Understandable \\
\hline Technology is critical to the work & Effort required to be skilled \\
\hline Finalization of more work & Frustrating
\end{tabular}

Source: adapted from Davis (1989) by the authors.

In both adaptations (reduction of variables), Davis (1989) used the Spearman-Brown formula, which relates the psychometric reliability to the duration of a test. The formula is used by psychometricians to predict the reliability of a test after changing the evaluation extension. Figure 1 presents the influences between the constructs at the TAM.

According to the TAM, users will probably accept a particular technology when they see its usefulness and ease-of-use (Oldacre 2016). The TAM is applied to understand the reasons for users to accept or reject certain technology, as well as to enhance its approval (Hora et al., 2018).

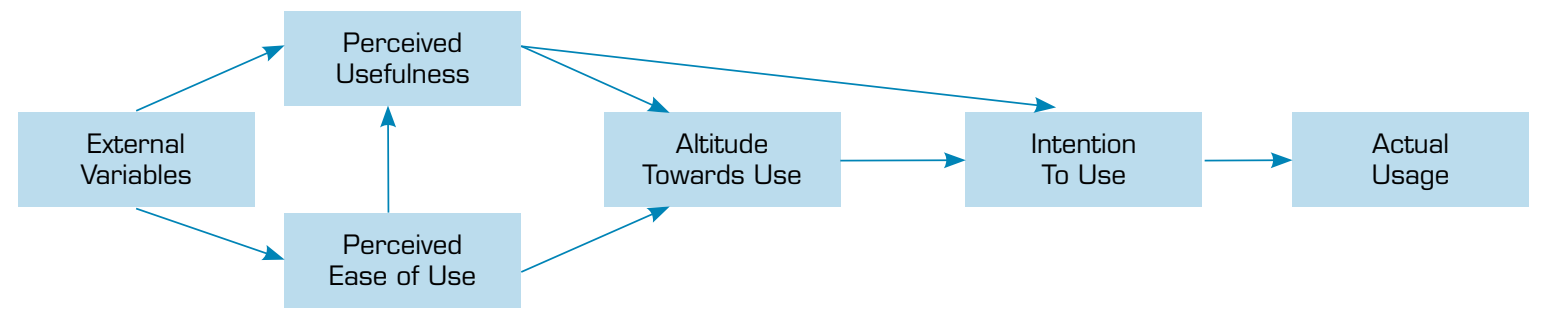

Figure 1. Technology acceptance model (TAM). Source: Davis, Bagozzi and Warshaw (1989). 


\section{Comparative Analysis of Technology Acceptance Models}

The TAM, proposed by Davis (1989), has undergone different modifications over the years (Rondan-Cataluña et al. 2015). In a research performed after the TAM creation, Davis and Venkatesh (1996) noticed that the PU and PEOU had a strong influence on the intention to use (IU) and the attitude towards use (A) would decrease after some time. Based on that, the authors decided to remove the Attitude construct from the original TAM (Davis 1989). Venkatesh (2000), based on social influences processes (subjective norms - SN, voluntariness and image) and instrumental cognitive processes (relevance at work, output quality, demonstration of results and PEOU), considered that these factors influenced the PU construct, and proposed the TAM 2.

As a way of unifying the TAM version, Venkatesh et al. (2003) proposed the Unified Theory of Acceptance and Use of Technology - UTAUT (Fig. 2).

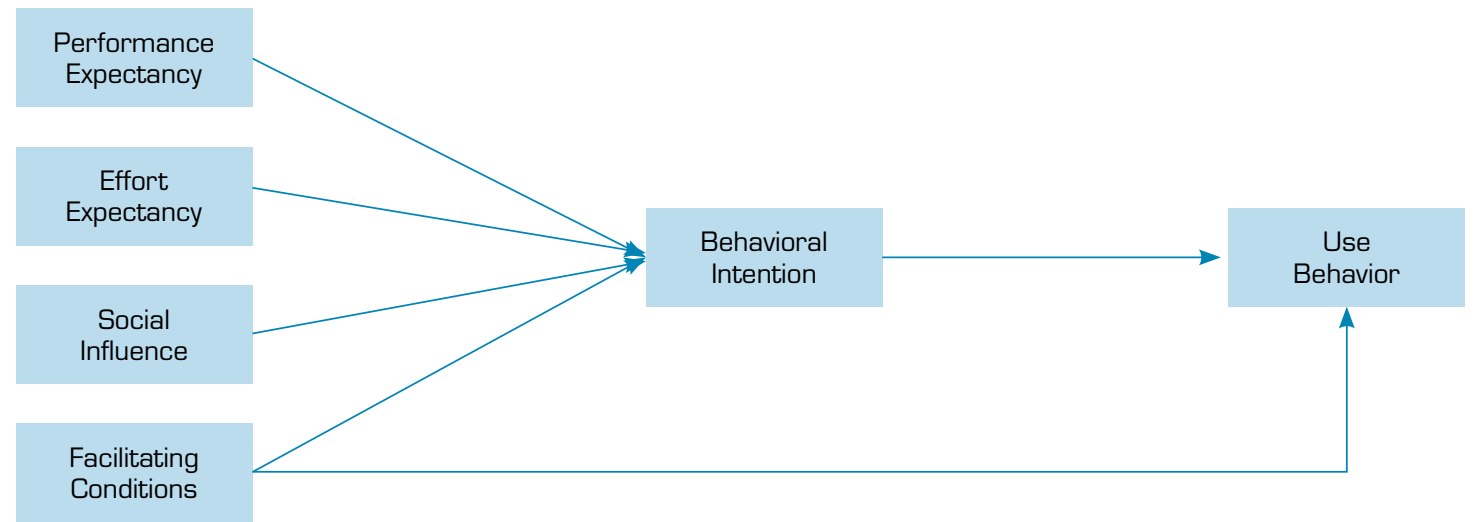

Figure 2. Unified theory of acceptance and use of technology. Source: Venkatesh et al. (2003).

Some years later, Venkatesh and Bala (2008) presented the TAM3 (Fig. 3). The authors expanded the constructs that precede the PEOU by adding two new groups, namely: (i) Anchor that is formed by the computer self-effectiveness, external control perception, computer anxiety, computer lucidity, and external control perception; and (ii) Adjustment that involves perceived pleasure and objective usability.

Even though the TAM has undergone modifications over the years, its different versions have been widely used to understand the adoption of technologies. The justification for using one or another model is based on the research goal and on the adequacy of the model constructs to the technology under analysis (Rondan-Cataluña et al. 2015).

Just as it occurred with the TAM, the UTAUT has undergone a modification in the study conducted by Venkatesh, Thong et al. (2012), in which three new determinants of the Behavioral Intention (BI) were added to constructs already applied by UTAUT, namely: hedonic motivation, price value, and habit. Moreover, the 'habit' construct was also associated with the Use Behavior (U), as in Fig. 4.

With the purpose of defining which model would be the best for the goal of this study (to analyse the perception of SERIPA investigators regarding the usefulness and ease of use of the RPAS equipment), we developed Table 2.

Based on the arguments in Table 2, the TAM proposed by Davis (1989) was the most suitable option for the general and specific goals of this study. We based our decision on choosing the TAM according to the follow characteristics of the other models: involvement of the user in the system development and nature of the deployment process (Davis and Venkatesh 1996); development or deployment process of an information system that does not match with the objective of this research; result demonstrability and voluntariness (Venkatesh 2000), social influence (Venkatesh et al. 2003), 'anchor' and 'adjustment' (Venkatesh and Bala 2008) and, finally, consumption or financial aspects (Venkatesh et al. 2012) are constructs that do not match with the objective of this research. The TAM does not have constructs and variables associated with the adoption of information systems. Thus, TAM presents more compliance with the objective of this research. 


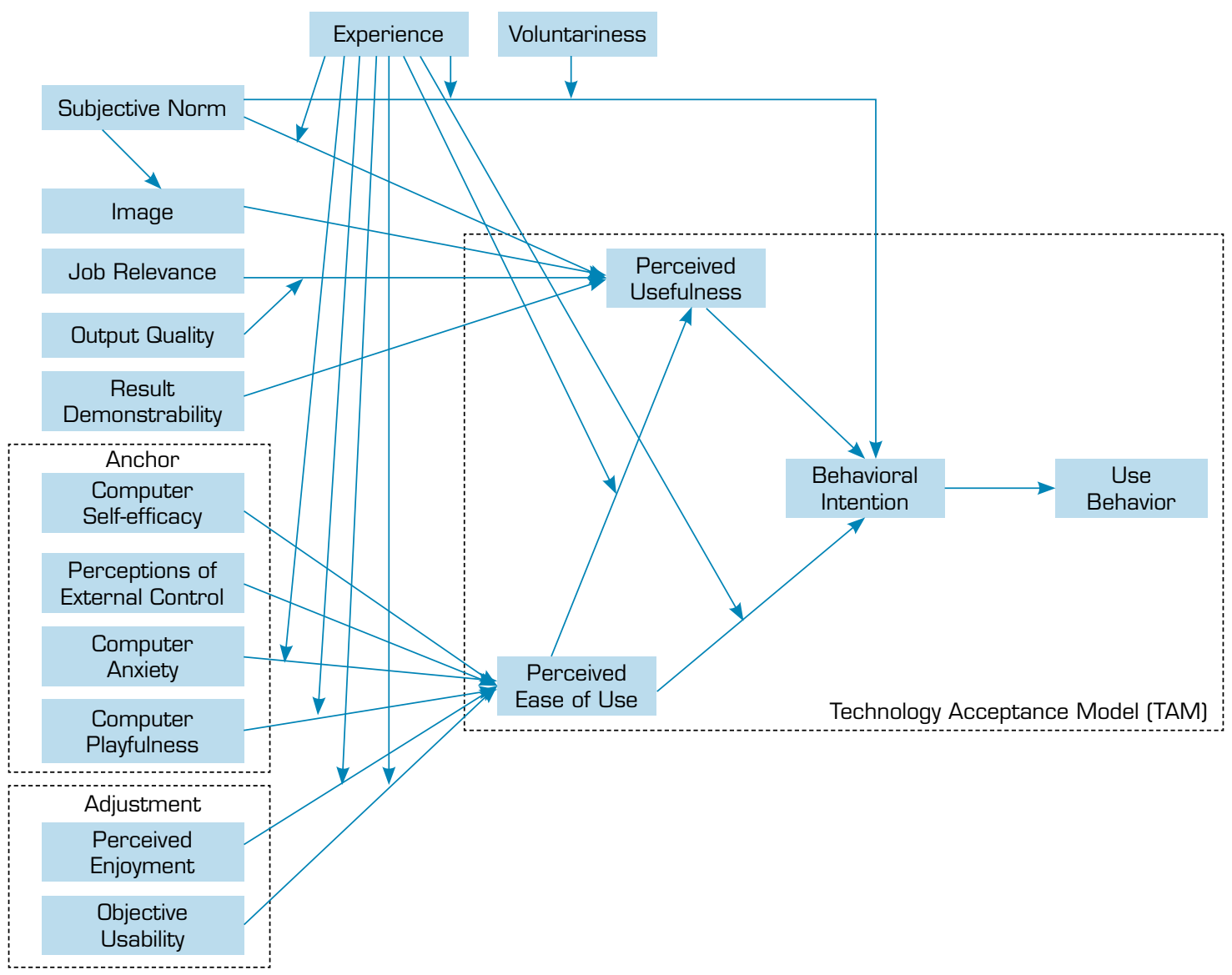

Figure 3. Technology acceptance model 3. Source: Venkatesh and Bala (2008).

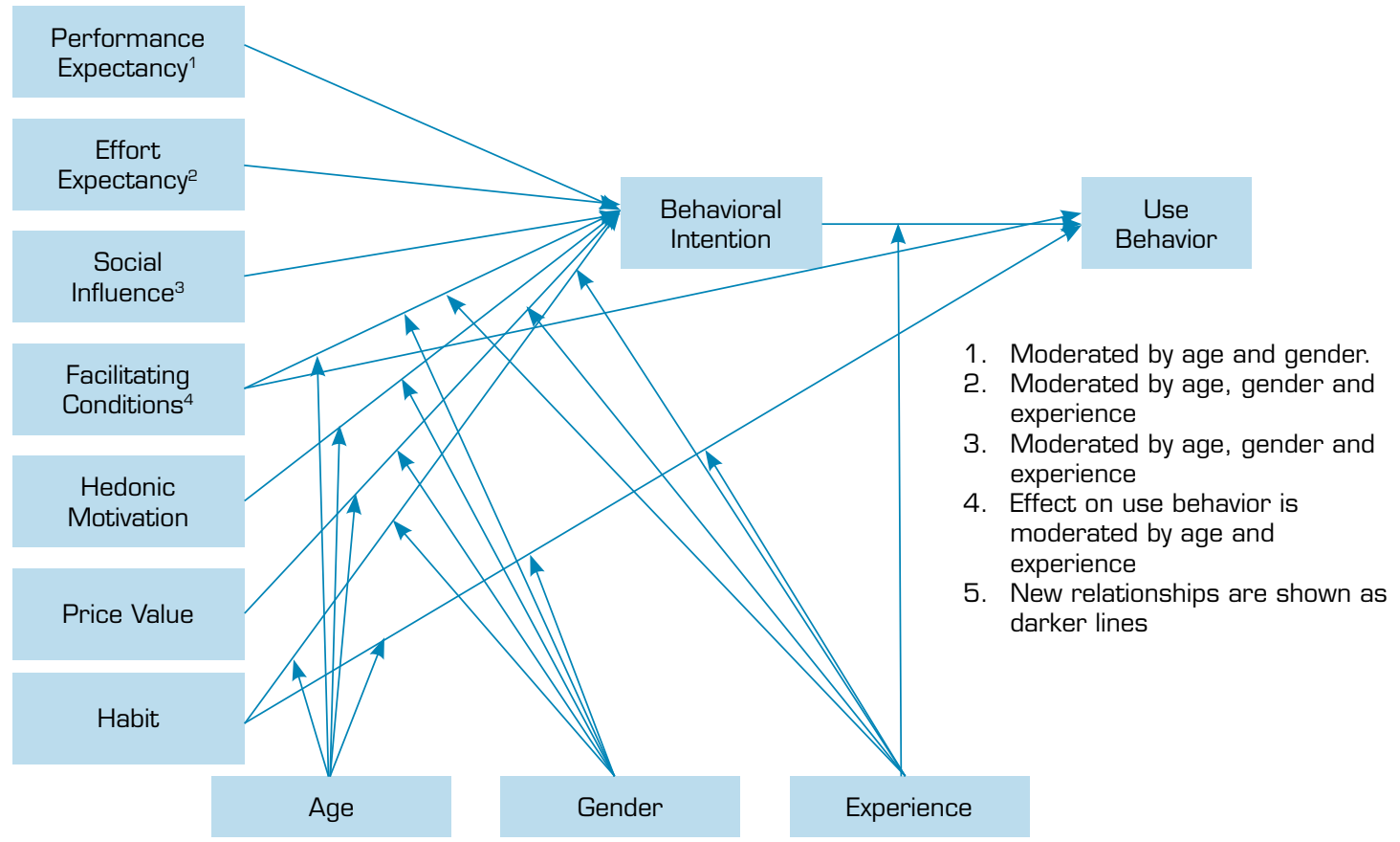

Figure 4. Unified theory of acceptance and use of technology 2. Source: Venkatesh et al. 2012. 
Table 2. Comparison of literature models to the study objective.

\begin{tabular}{|c|c|c|}
\hline Model & Model constructs & Analysis of model adequacy to the study objective \\
\hline $\begin{array}{l}\text { TAM (Davis } \\
\text { 1989) }\end{array}$ & $\begin{array}{c}\text { External variables, perceived usefulness, } \\
\text { perceived ease of use, attitude, intention } \\
\text { to use }\end{array}$ & $\begin{array}{l}\text { Used in the study due to higher suitability of the constructs to the } \\
\text { study objective. TAM is more suitable to be used in this study because } \\
\text { it does not have constructs and variables associated with consumption } \\
\text { or financial aspects that are not applicable to the work context }\end{array}$ \\
\hline $\begin{array}{l}\text { TAM } 1 \\
\text { (Davis and } \\
\text { Venkatesh } \\
\text { 1996) }\end{array}$ & $\begin{array}{l}\text { External variables, perceived usefulness, } \\
\text { perceived ease of use, behavioral intention }\end{array}$ & $\begin{array}{c}\text { The TAM } 1 \text { was adapted to assess the adoption of information } \\
\text { systems, with the following items being incorporated into its } \\
\text { external variables: system characteristics, involvement of the user } \\
\text { in the system development and nature of the deployment process. } \\
\text { We considered the variables incorporated to the TAM } 1 \text { as } \\
\text { incompatible to the goal of this study and therefore we discarded } \\
\text { their use in the research }\end{array}$ \\
\hline $\begin{array}{l}\text { TAM } 2 \\
\text { (Venkatesh } \\
\text { 2000) }\end{array}$ & $\begin{array}{l}\text { Subjective norm, image, job relevance, output } \\
\text { quality, result demonstrability, experience, } \\
\text { voluntariness, perceived usefulness, perceived } \\
\text { ease of use, intention to use, use behavior }\end{array}$ & $\begin{array}{l}\text { The TAM } 2 \text { followed the same objective of the TAM } 1 \text { in the sense } \\
\text { of adding variables that could explain the adoption of information } \\
\text { systems in a better way. Variables that preceded the perceived } \\
\text { usefulness construct, such as: Job Relevance, Output Quality, } \\
\text { Result Demonstrability and Voluntariness were added to the model. } \\
\text { These variables are not related to the goal of this study and } \\
\text { therefore we discarded the model }\end{array}$ \\
\hline $\begin{array}{l}\text { UTAUT } \\
\text { (Venkatesh } \\
\text { et al. 2003) }\end{array}$ & $\begin{array}{l}\text { Performance expectancy, effort expectancy, } \\
\text { social influence, facilitating conditions, } \\
\text { behavioral intention, use behavioral }\end{array}$ & $\begin{array}{l}\text { The UTAUT was developed with the purpose of unifying the previous } \\
\text { proposals of models that has been developed so far (TAM, TAM } 1 \\
\text { and TAM 2). The following constructs were added: performance } \\
\text { expectancy, effort expectancy, social influence, facilitating conditions. } \\
\text { The model was maintained with the purpose of assessing information } \\
\text { systems. We discarded this model due to the inadequacy of the } \\
\text { constructs to the research goal }\end{array}$ \\
\hline $\begin{array}{l}\text { TAM } 3 \\
\text { [Venkatesh } \\
\text { and Bala } \\
\text { 2008) }\end{array}$ & $\begin{array}{l}\text { Experience, voluntariness, subjective norm, } \\
\text { image, job relevance, output quality, result } \\
\text { demonstrability, anchor, adjustment, perceived } \\
\text { usefulness, perceived ease of use, behavioral } \\
\text { intention, use behavior }\end{array}$ & $\begin{array}{l}\text { The TAM } 3 \text { was presented some years after the UTAUT model and } \\
\text { brought several changes, especially with regard to constructs that } \\
\text { preceded the perceived usefulness and ease of use. The 'anchor' and } \\
\text { 'adjustment' of constructs had variables that are not applicable to the } \\
\text { context of this study; therefore, the model was disregarded due to the } \\
\text { inadequacy of the constructs to the research goal }\end{array}$ \\
\hline $\begin{array}{l}\text { UTAUT } 2 \\
\text { (Venkatesh, } \\
\text { Thong and } \\
\text { Xu 2012) }\end{array}$ & $\begin{array}{l}\text { Performance expectancy, effort expectancy, } \\
\text { social influence, facilitating conditions, } \\
\text { hedonic motivation, price value, habit, } \\
\text { behavioral intention, use behavioral, age, } \\
\text { gender, experience }\end{array}$ & $\begin{array}{l}\text { The UTAUT } 2 \text { was developed in order to provide the analysis of the } \\
\text { consumer's behavior. The UTAUT } 2 \text { model focus on the behavior } \\
\text { analysis that is not related to the goal of this study, and its use } \\
\text { was discarded. }\end{array}$ \\
\hline
\end{tabular}

Source: developed by the authors (2019). TAM: Technology acceptance model; UTAUT: Unified Theory of Acceptance and Use of Technology.

\section{METHODOLOGY}

The research nature was classified as an 'applied' type due to the fact that the study seeks the production of knowledge for practical application in relation to the reduced use of RPAS by SERIPA (Silveira and Códova 2009). Regarding the objective, the study was classified as an exploratory research because it presents a bibliographic review of the researched subject and interviews with researchers with practical experience in RPAS at SERIPA. Moreover, the subject is relatively recent in origin. According to Gil (2008), the exploratory research aims to introduce a greater familiarity with the problem to make it more understandable.

Methodological procedures were based on bibliographic research conducted following scientific articles, books, official documents of the Brazilian Aeronautics, master and doctoral theses (Walliman 2018), and semi-structured interviews (Gil 2008). The study approach was qualitative and carried out by means of a case study and inductive logic. Silveira and Códoba (2009) consider qualitative research as one without numerical representation in the answers. For Cervo et al. 2006, p. 36, "the premises of an inductive argument support or attribute a certain likelihood to its conclusion." As for the technique of data collection, the semi-structured interview procedure was used to obtain knowledge on the perception of those involved about the usefulness and ease of use of RPAS. SERIPA investigators were 
interviewed with questions associated with the perception of the equipment utility, the RPAS ease-use perception, and the intended use of the tool. To meet best practices in academic research, the study was submitted to the Research Ethics Committee (REC) and approved under CAAE (Certificate of Presentation for Ethical Appreciation) 90860718.6.0000.5111. The interviews were guided by 26 questions based on the variables defined by the Theory of Rational Action (TRA) and the TAM (Table 3).

Table 3. Constructs, variables, and theoretical basis applied in research.

\begin{tabular}{|c|c|c|c|c|}
\hline Construct & Variables & Description & Reference & Theory \\
\hline \multirow{3}{*}{$\begin{array}{c}\text { External } \\
\text { variables (VE) }\end{array}$} & $\begin{array}{l}\text { Experience/ } \\
\text { previous use }\end{array}$ & $\begin{array}{c}\text { Form of specific knowledge or skill that } \\
\text { was acquired through systematic learning, } \\
\text { improving over time; practice }\end{array}$ & \multirow{3}{*}{$\begin{array}{c}\text { Fishbein and Ajzen } \\
\text { (1975), Davis et al. } \\
\text { (1989) }\end{array}$} & \multirow{3}{*}{ TRA, TAN } \\
\hline & Documentation & $\begin{array}{l}\text { Use of handbooks for obtaining } \\
\text { knowledge about a particular subject }\end{array}$ & & \\
\hline & Training/ suitability & Preparation, ability to develop skills & & \\
\hline \multirow{6}{*}{$\begin{array}{l}\text { Perceived } \\
\text { usefulness (UP) }\end{array}$} & $\begin{array}{l}\text { Quality } \\
\text { of work }\end{array}$ & $\begin{array}{l}\text { Property that determines the essence } \\
\text { or nature of a being or thing }\end{array}$ & \multirow{6}{*}{ Davis et al. (1989) } & \multirow{6}{*}{ TAM } \\
\hline & Useful & $\begin{array}{l}\text { The beneficial use of something; the service provided by } \\
\text { someone or something; use }\end{array}$ & & \\
\hline & Fast work & Quality of what or who is fast; speed, lightly; brevity & & \\
\hline & Work performance & Performance & & \\
\hline & Effectiveness & Real effect & & \\
\hline & $\begin{array}{l}\text { Transforms/ } \\
\text { leaves the job easier }\end{array}$ & Facilitator & & \\
\hline \multirow{6}{*}{$\begin{array}{l}\text { Perceived ease } \\
\text { of use (FUP) }\end{array}$} & Ease-of-use & Skill in handling the equipment & \multirow{6}{*}{ Davis et al. (1989) } & \multirow{6}{*}{ TAM } \\
\hline & Mental effort & Degree of difficulty understanding & & \\
\hline & Comprehensible & Subject to be understood, perceived; intelligible & & \\
\hline & Easy to remember & $\begin{array}{l}\text { Functions of commands and } \\
\text { controls are easy to remember }\end{array}$ & & \\
\hline & Controllable & Degree of equipment controllability & & \\
\hline & Frustration & $\begin{array}{l}\text { Feeling of incapacity in the face of obstacles that } \\
\text { are difficult to overcome and that prevent one from } \\
\text { achieving the satisfaction of a determined requirement }\end{array}$ & & \\
\hline $\begin{array}{l}\text { Behavioral } \\
\text { intention of } \\
\text { use (IC) }\end{array}$ & $\begin{array}{l}\text { Attitude }+ \text { perceived } \\
\text { utility }\end{array}$ & $\begin{array}{l}\text { Attitude in using the technology; } \\
\text { considers useful technology }\end{array}$ & Davis et al. (1989) & TAM \\
\hline
\end{tabular}

Source: developed by the authors (2019). TAM: Technology acceptance model.

Most of the interviews were conducted in person with the SERIPA investigators, with the exception of two investigators, who were interviewed via telephone conversation. All the dialogues were recorded in audio and transcribed in full. The interviewees were identified with the letter "E" followed by a sequential number (E1-E14) in order to preserve the identity of the participants.

Interviews took place during the second half of June 2018. The analysis of research data used the technique of content analysis proposed by Bardin (2016). The technique can be defined as "a set of techniques of communication analysis that uses systematic procedures and content description of objectives of messages" (Bardin 2016).

The data collected from the interviews were organized in Microsoft Excel spreadsheets and grouped according to the variables and constructs of the interview script. The objective was to identify the main themes of each researched subject, new themes and the reoccurrences or not in the answers. The last stage was the treatment of the results obtained and their interpretation (Bardin 2016). 


\section{ANALYSIS AND RESULTS}

Research participants belong to different SERIPA and have, in their majority, academic background in the Brazilian Air Force. Most interviewees (11) are official airmen trained by the Air Force Academy between 2000 and 2010; the predominant age range, between this group, was 32 to 39 years. Three research participants are graduates, specialists in aircraft maintenance, whose training took place between 1981 and 1989 at the EEAR (Escola de Especialistas da Aeronáutica - School of Aeronautical Specialists); predominant age range, between this group, was 48 to 55 years. Three interviewees (E10, E11 and E14) were from SERIPA in Recife city (State of Pernambuco) and three (E8, E12 and E13) from SERIPA in Belém city (State of Pará), both states are in Northeast Brazil. Respondents E6 and E7 are from SERIPA in Brasília city (Federal District - Central-western Brazil) and respondents E3 and E5 from Canoas city (State of Rio Grande do Sul - Southern Brazil). Finally, interviewee E9 is from SERIPA in Rio de Janeiro city (State of Rio de Janeiro - Southeast of Brazil).

\section{External variables}

In relation to the previous experience of respondents with RPAS and model aircraft, only six investigators had had any contact with this equipment category. Therefore, the use of RPAS can be considered low by the analyzed investigators.

I have some friends of mine with simpler models than we have here on the SERIPA. I have already an experience in RPAS commands, which facilitated the use here (SERIPA). (E10)

[...] I bought a model airplane to play with. I like it. The difference between the model airplane is absurd. I used more the knowledge of helicopter aerodynamics to fly the model than RPAS. RPAS is much more stable, it is a quieter operation. (E13)

[...] My previous experience with model airplanes was very small. I flew very little just during the first year of EPCAR (Air Cadet Preparatory School), then I left. And the first contact I had with RPAS was here at SERIPA, I had no previous experience. I participated in the model airplane club. I had a club house and the flights were held at the airport, with NOTAM (notice to airmen), or at the stadium. (E14)

Regarding the knowledge acquired for operation, with the use of the RPAS manual, respondents (8) highlighted not only the logical sequence of the document as positive, but also the objectivity and simplicity.

For the operation, you have to stick to the limitations of the device. You have to know how long it lasts, how far you can go. (E2)

[...] Straight, somewhat shallow. Enough for you to understand, get the drone, take off, do a simple flight, land, over. It is enough to operate simple flight. If you are just reading the manual and is flying, it will take a few frights. (E4)

[...] The facility is the trivial reading, which has a logical sequence of the assembly process and use. Difficulty I have not actually found. It is not so big. (E10)

When the interviewees were asked about the level of knowledge of the laws dealing with the use of RPAS (94E RBAC and ICA 100-40), they demonstrated a satisfactory understanding. The importance of the laws (94E RBAC and ICA 100-40) was emphasised, especially the limits of the operation, in order not to expose the aircraft and third parties to risk. 
[...] I found very important this part about notification, a matter of weight, as it classifies, as you have to register at ANAC, the issue of not flying over people, in a safe place, flying away from obstacles, interference, issues of flight safety. And responsibility... That it is not just a toy. (E5)

[...] My first contact was with the ICA 100-40. There are several issues, both DECEA and ANAC. They are involved in two segments: one oversees this part of legislation (RBAC 64E), the other manages the airspace. (E13)

All respondents stated that the RPAS training was sufficient for the RPAS pilot training. In addition, respondents stated that the training provided more security to operate RPAS in real-life situations. The simulations performed in the training were relevant and close to the reality that RPAS operators can find in a real crash site. A theme that could be improved, in the view of respondents, is related to the laws that address the issue.

[...] I thought it was cool. I do not know if it is the Aviator's perception, I did not feel any difficulties. The flight of the drone itself is quiet. Then when we operated with graduates, I found that it was not the same thing. They felt more difficulties, especially fear. For me it was appropriate enough. I feel fit. (E4)

[...] What I think I missed, which at the time was really stumbling, when we did the course, is part of legislation. So, in training, the legislation has to be shown. Because sometimes the person does not even know what are the laws that deal with the subject. (E9)

Based on interviews, six investigators were unaware of the existence of the RPAS simulator software used during training. Although this feature has been commented during the original training in the CENIPA (with the Group), the comments about RPAS simulator software were not extensive. The remaining respondents stressed the benefits of the simulator use to highlight the feature to facilitate learning. Another point that was repeatedly mentioned is based on the impossibility of damaging the unit (RPAS equipment), based on the errors made.

[...] I thought it was essential. I found it very similar to the RPAS response. It made it a lot easier. The control is the same. I am in patrol aviation. The reflexes are different. We saw that the guys in the helicopter were learning a lot faster. It would take much longer if I did not have the simulator. (E8)

[...] The simulator is indispensable. It is important because you get the tact, so I think the simulator is indispensable for flight safety. It made learning easier. You could "make a mistake" in the simulator, without causing damage to anyone, nor damaging the equipment. (E10)

We observed from analysis that the majority of interviewees had some previous contact with RPAS or model airplanes. This was not determinant for their training, once the operators considered themselves fit to use the equipment after the training. Interviewees demonstrated knowledge of the manuals and the legislation for RPAS operation. Flight simulator use was recognized as a learning facilitator. Table 4 summarizes the main results to the construct of external variables.

The results, when compared to those presented by Rangel (2018), are similar. The training of RPAS investigators in simulated practices (flight simulator) and regulations increases safety in the equipment operation. Analysis of results allows to infer that greater experience and usage of the equipment, usage of flight simulators, and knowledge of regulations influence the RPAS operation safety. 
Table 4. Results of external variables.

\section{Research results}

\begin{tabular}{c} 
Research results \\
\hline$[\ldots]$ the majority of interviewees had some previous contact with RPAS or model airplanes \\
\hline Prior contact of respondents with RPAS or model airplanes \\
was not observed as a prerequisite for the operation of RPAS \\
A manual with a logical sequence, objectivity and simplicity \\
can improve, quickly, the knowledge to operate a RPAS
\end{tabular}

Flight simulator use was recognized as a facilitator in learning
TAM variable - based on Table 3

Experience/previous use

Documentation/training/ suitability

Source: developed by the authors (2019). TAM: Technology acceptance model.

\section{Perceived usefulness}

When asked about the possible improvements, in terms of quality, related to the investigation of aviation accidents using the RPAS, respondents noted the possibility of modelling the occurrence in $3 \mathrm{D}$ software, preserving the evidence in digital form. In addition, they were positive about the ability of RPAS to show the crash site in its entirety, conveying a greater amount of detail. Another improvement was that the sketch pointed the accident using pictures of occurrence, improving the graphical representation of the events, in the reports.

[...] We will have a photo shoot and the possibility of being able to model the scenario. That is a gain we will have for sure! Because you, in the future, could have a question: "I have a play. It was in such a place, but I do not remember the distance, at that moment I did not measure." So, I will measure in modeling. (E1)

[...] The biggest gain for research is that you can do an analysis after the initial action, which you certainly will not see on time or through picture. With the drone, especially on filming function (drone's camera is excellent), it (drone's camera) allows you to make a more extended analysis. The investigation is far richer in details. (E4)

Asked about the usefulness of RPAS, in regard to view the crash site, as well as if this equipment could help understand the dynamics of an aviation accident, investigators considered it a useful tool. They reported the high ability to be possible using the generated images to refute or confirm a hypothesis raised during an investigation.

[...] Through a shoot you can take the home from the wreckage, then you go traveling, doing a complete footage of the aircraft route, to simulate the route. It helps to confirm or refute a hypothesis. (E6)

[...] If the wreckage is concentrated, the utility gets smaller. But if the wreckage is scattered, a bird's-eye view, an air outlet gives you a sense of direction, aircraft movement, which I think it is very important. It greatly facilitates our work. You can have the dynamism of occurrence. (E10)

To compare the time spent for performing aerial images, using the equipment (in this latter case, engaging airplanes or helicopters from third parties), respondents were positive by saying that the RPAS appreciably reduces the period necessary for obtaining the photos. They highlighted that the quality of the images would be greater if using the RPAS, due to the equipment stability and the possibility of approaching the wreckage without making the place of occurrence, compared with manned aircraft. 
Furthermore, it is appropriate to mention the impression of investigators regarding the cost to the image capture. The investigators were emphatic to report that the expense would be considerably reduced with the use of the equipment.

Certainly, it decreases the costs! Because I am going to get there in time for initial action with my drone, I am going to take off and I am going to take my pictures. I will not depend on anybody (from another aircraft). (E1)

[...] I have taken photos with the drone and I have caught up with plane and helicopter too. In a helicopter, you will not get the same drone placement. The image will not be the same, will not have the same quality, there is no comparison! The drone takes a much shorter time than the helicopter to take photos. It would have to be with a helicopter or fixed-wing aircraft, not to mention the cost. (E3)

Regarding the improvement of professional performance with the use of RPAS, users have commented on the possibility of conducting more extensive analyses, with the acquisition of additional information about occurrences, especially under other angles.

[...] I am going to be able to collect information that, suddenly, if I did not have an air support, I would not be able to. Otherwise, I would not be able to perform an analysis as appropriate, or a much deeper one as I would like without this information. (E2)

[...] You have perceptions with the drone in the vertical direction that you would not have if there was not. It can greatly improve the investigator's perception. He/she offers other angles that I did not have, if compared with an investigation that has not. (E7)

Confronting your expectations and the obtained results, respondents judged the RPAS as an effective equipment. There was testimony of overcoming this expectation, depending on the quality of the images and the generated products.

It was more than what I expected. For me, it was just hitting a shot, but when the guy showed me that all modeling, scenario assembled in 3D, was almost equal to what we see there, it was fantastic! (E1)

[...] Actually, at practice, it exceeded expectations. I thought it would be time-consuming to get something of quality, but I saw it is pretty simple, and we can do this. It exceeded my previous expectations. It meets the objectives it sets out to do and goes beyond. (E8)

The investigators concluded that the RPAS can facilitate the investigation of aviation accidents. According to the reports, the equipment can register better details and allows the approach of places that are hard to reach.

It facilitates a better viewing and collecting more details of the occurrence place. (E1)

[...] It allows viewing in multiple angles, cataloging wrecks, as well as in an urban area with great dispersion of wreckage. If the aircraft collided with mains wiring, the drone allows get the images exactly on the site of the collision (mains wiring height) and catalog the direction of the aircraft. (E3) 
Analysis suggests the RPAS can improve the quality of investigations and is useful for understanding an air accident dynamic. We observed that the equipment (RPAS) significantly reduces the time of obtaining aerial images, as well as the cost for obtaining them. The analyses have similarities with the study performed by Gomez et al. (2017), who concluded RPAS is a useful tool for investigating aircraft accidents at a much lower cost than using a commercial helicopter. Hawkins (2016) adds that RPAS costs significantly less than manned aircraft and is capable of flying in low visibility and low cloud conditions (which would disrupt the operation of an aircraft or helicopter).

For Gomez et al. (2017), RPAS is able to mitigate the risks associated with investigators of aeronautical accidents by enabling a safer visualization of the location. Hawkins (2016) highlights that RPAS is able to fly close to trees and wreckage in order to obtain close-up images, without changing them with the rotor downwash. Table 5 summarizes the main results to perceived usefulness construct.

Table 5. Perceived usefulness results.

Research results

[...] the investigators consider the equipment to have the capacity of improving the quality of investigations, and it is useful to understand an aeronautical accident dynamic

It was evident the impression that the device significantly reduces time to obtain aerial images, as well as the cost for this acquisition Possibility of replacing manned aircraft by RPAS

\section{TAM variable - based on Table 3}

Improves quality of work

Useful to understand an aeronautical accident dynamic

Helps to work faster

Improves work performance

Effectiveness - refers to real effect - RPAS reduces the cost and time to obtain aerial images

Transforms/leaves the job easier (possibility of replacing manned aircrafts by RPAS)

Source: developed by the authors (2019). TAM: Technology acceptance model.

The results showed that the 'perceived usefulness' construct of the RPAS has a strong influence on the attitude and usage intention in all variables of the TAM model (Table 5). The possibility of replacing manned aircraft with the equipment was the most relevant factor.

\section{Perceived ease of use}

In sequence, we analyzed the ease-of-use level of the RPAS, particularly in transport, installation, and operation. The investigators deemed the simple handling equipment and highlighted the difficulty in bringing the equipment into their briefcase, when travelling on commercial aircraft, due to reduced available space in the bin (compartments located on top of the aircraft cabins, meant to guard passenger luggage), as well as a volume to be transported.

The storage case containing the RPAS sometimes gets in the way, because it is a little big. The assembly is simple, has no difficulty, it is fast. The operation of the drone is not difficult. (E12)

[...] With respect to the assembly and use, I thought they were very simple. The only downside is the transport. I see it as a weakness, because we have to move sometimes in the woods, in a marshy region, and there is the load weight in addition to the equipment of the early action. The case gets in the way a little. (E8)

Investigators reported full understanding of the safety requirements for use, due to the simplicity of the precepts.

They are easy to understand. Do not fly near people, around metals to avoid interference. No trouble about understanding the safety requirements. (E5) 
[...] Safety requirements are simple, like: Do not pass over the crowd! It is easy to understand. I do not see any difficulties in understanding it. They are easy (the rules) because it is pretty clear to understand the laws there, they have specified well. Good, clear, simple goal. (E10)

When pairing the controller, the aircraft and the tablet, respondents considered this action as a simple procedure. They compared it, by similarity, with a wi-fi network connection.

It is simple. I did not face any difficulties to connect the drone, the control, and the tablet. It is similar to a cell phone, a wi-fi network. (E4)

It is very simple, really. Push in there, "SYNCHRONIZE", and that is synchronized. It is a technology that we are already using today. (E14)

When it comes to understanding the $\mathrm{SOLO}^{\odot}$ software, for the operation of the RPAS, investigators expressed clarity of the provided information.

The information is clear. The software is simple and has everything required for proper operation. I had no questions regarding understanding the information. (E9).

Clear information, visualization. Information that is easy to understand. The icon over there just clicks, there is a message on the screen, this facilitated. The icon talks to me when I look at it. (E13)

[...] It is quiet. For those who have a certain intimacy with that part of its technology, it ( $\mathrm{SOLO}^{\odot}$ software) gives you a friendly platform. Once it $\left(\mathrm{SOLO}^{\circ}\right.$ software) did not leave the drone call, I was at an angle, and rang that alarm and I understood what it $\left(\mathrm{SOLO}^{\circ}\right.$ software) was trying to tell me. (E12)

With respect to the information in the interface (battery life, distance, altitude), the opinion of the investigators on the level of ease for visualization showed that they consider it of easy perception. There were indications regarding the battery life and sound alerts. The difficulty in observing the information on the tablet and driver, in a position that allows the reflection of sunlight, was cited as a negative highlight.

Its viewing is easy too. The number is not so high, though. It could be a little higher, but it is got the warnings too. When we are running out of battery, it shakes the control there, it has got more warnings, it talks. (E5)

The screen shows the battery capacity, all the information is on the screen. Of course, you have to be careful in viewing the sun, which can disrupt the vision there on the screen, but the information there is clear, easy to understand. (E10)

Asked in relation to controls (joysticks and buttons) and commands on the tablet, respondents commented on how easy was to remember their functions. Although they consider the intuitive controls, investigators showed the importance of training, with emphasis on the use of the simulator. An operator (pilot of rotorcraft) reported the reversal of commands, notably, in the sense of up and down. 
I think it is easy, simple, and intuitive. It already has the buttons in the control saying that they serve to fly, start, etc. Then, the control itself is intuitive. (E3)

[...] By having an experience as pilot, just that one little riot of up and down. I am used to pull up and push down. And the control is reversed. (E13)

The investigators expressed their opinions about the difficulties and facilities on landing and takeoff operations. The greatest difficulty was to find a suitable location for the procedures, according to the relief. Consider the simple execution actions, mainly in self-mode, in which there were reports of restlessness at the beginning of the use.

Difficulty: find an ideal location, especially on the accident site. In relation to the joystick, I did not have any difficulties in takeoff and landing. (E1)

[...] I thought it was pretty simple. In manual mode, we always put down and takeoff quickly, to avoid a larger wind influence. As it has a ground effect and a stronger wind, we always put or take the ground fast, so it does not tip over. (E5)

When using the RPAS, investigators identified a sense of satisfaction. They emphasized the fact that it is a new and useful technology.

The drone itself is very pleasant. It is a technology that is here to stay and that is quite useful. (E7)

Satisfaction, because I was using a new and very useful. It is a piece of equipment that today became the 'eyes of the world' Everyone wants to have and everybody has it. I have one at work and I use it for work. (E1)

It is really a pleasure. Despite being 'work', it is fun. It is interesting, different, not a very common technology. In addition to facilitating work, it is cool to use it. (E8)

On one hand, observing comments on the ease of use, one realizes that the main stumbling block pointed to by the interviewees is the difficulty of transporting the equipment on commercial aircraft. On the other hand, investigators reported the simplicity to perform assembly, flights, takeoffs and landings, pairing with the tablet and controller, as well as the ease of viewing the information in the interface. Table 6 summarizes the main results to the PEOU construct.

After their experiences in the use of the RPAS, respondents recommended the use of the equipment. There were exceptions as to the indication of the use only in situations that are difficult to access and in more complex instances. The difficulty in transporting was cited once more.

I would recommend to some investigations. In some investigations, like ... a run-off, or going away and going by plane, due to the difficulty of transportation, it will bring you many benefits. It all depends on the investigation, every case is different. (E5). 
Table 6. Results of perceived ease of use.

\section{Research results}

[...] in the comments of the ease of use, it is noticed that the main obstacle pointed out by the interviewees is the difficulty to transport the equipment in commercial aircraft

Investigators reported the simplicity to carry out the assembly, flights, landings and takeoffs, the pairing with the tablet and controller, as well as the ease of viewing the information in the interface

The investigators stated that the RPAS control is simple (ease-of-use) and does not present learning difficulty (mental effort) or comprehensible commands to be performed. The few existing commands to control the RPAS make it easier to remember the actions that can be performed

RPAS is simple to control (controllable), even for those who have never had previous experiences

No frustration has been observed by investigators when using RPAS

\section{TAM variable - based on Table 3}

RPAS is easy to pilot (simplicity to carry out the assembly, flights, landings and takeoffs]

RPAS does not present learning difficulty (little mental effort to pairing with the tablet and controller, as well as viewing the information in the interface]

RPAS commands are comprehensible (simple and few)

RPAS control is easy to be performed (controllable)

Source: developed by the authors (2019). TAM: Technology acceptance model. Behavioral intention of use

As to the motivation for using the RPAS, all investigators have shown excitement about the tool. The obstacles with the transport were classified as an unfavorable factor.

Using the equipment, I can deliver a product to society with a better quality than that if I had not used it. So, it motivates! (E3)

I would use the equipment all the time. By amenities, for what it gives you. The bad news is more for mobility. (E6)

My motivation is high. The only thing we think as to not take it is the difficulty of transport. (E8)

About their expectations for using it in future missions, investigators (12) spoke so incontrovertible that a preliminary assessment is required. Such judgment is based, primarily, on the difficulties arising from displacement.

Maybe it is not worth. For example, the aircraft crashed in a river. I do not know to what extent it would be interesting because it is submerged. (E7)

Our idea is to take it whenever possible. If we know that it is going to a flooded region, and we are going to have to get with winch, or helicopter, it gets really complicated. If we are going by car, if possible, we take it. (E8)

The issue of RPAS transportation is that it would make more use of this tool. Because if there was the possibility, it could be used in all the offsets and there you would define the need of using it or not. (E9)

[...] Each case is different. If we go by car, we take it! If we travel by plane, then we must see what the scenario is. A chance that even I would take it would be a plane crash in the water. Do I go swimming to the plane? If I put the drone in the water (flying), on top of the plane, it helps me a lot. (E14)

In conclusion, after analyzing the answers on behavioral intention, the respondents recommend the use of the tool for accident investigation. Even though they are excited about the new equipment, the investigators were assertive that there must be a prior 
analysis of the occurrence, especially considering which way it will be possible to reach the location of the crash site, to then decide the use of the RPAS. Table 7 summarizes the main results of behavioral intention of use construct.

The results of this study can be compared to those presented by Nunes (2017), in which the RPAS was observed as useful for visualizing areas of difficult access and pre-assessment of an accident. For Nunes (2017), RPAS helps to take decisions in catastrophes. RPAS investigators of SERIPA that were assessed informed that it is difficult to transport the equipment to the accident site, which makes its use often non-viable. The results of this study are different from those presented by Constantinescu and Nedelcut (2011) and Alfaro (2015), in which the RPAS was considered easy to transport. The divergence in the results is justified by the fact that Constantinescu and Nedelcut (2011) and Alfaro (2015) considered the transport of the RPAS in a vehicle, while RPAS investigators of SERIPA quite often need to transport the equipment in commercial airplanes.

Table 7. Results of behavioral intention of use.

Considering behavioral intention, we concluded that the interviewees recommend the use of the tool (RPAS) for accident investigation

Even though there is excitement with the new equipment, the investigators were assertive that it is necessary to analyze the occurrence beforehand, especially taking into account how it will be possible to get to the crash site, and then decide whether to use RPAS or not

Characteristics of the crash site should be taken into consideration by the investigator. In an air accident in a flooded region or on a river/sea, the RPAS may not be useful

Source: Developed by the authors (2019]. TAM: Technology acceptance model.

\section{CONCLUSIONS}

Returning to the original question of this study, we concluded that the investigators find the tool useful and easy to use. When evaluating the perception of RPAS usefulness, according to the investigators, we concluded the RPAS can be applied in an investigation of aviation accidents as a support tool. RPAS was considered a technology that can bring improvements in the analysis capacity of investigators and reduction in the costs of investigations of aeronautical accidents at the scope of SERIPA. RPAS investigators training was more simple, efficient, and had a lower cost than using aircrafts such as helicopters, often used in the investigation of aircraft accidents. The study demonstrated that the risk associated with the investigator for collecting evidence is considerably reduced with the use of RPAS. The analyses made possible to infer that the type of transport the investigator will use in order to arrive at the accident location and the location itself influences the attitude and the perceived usefulness of RPAS. We believe this information may help investigation organizations and investigators of aeronautical accidents in the decision of whether to use or not a RPAS in an aeronautical accident. The way the investigator will get to the investigation area should be assessed by investigation organizations of aircraft accidents in a cost-effectiveness relation in RPAS use.

The study made possible to notice the benefits of RPAS use in the investigation of aeronautical accidents. Moreover, we discussed the inhibiting factors of using the RPAS technology in an air crash site. After the analysis and results both assumptions presented at the beginning of this research (P1 and P2) have been refuted:

- P1: investigators of the accident consider RPAS a useless tool, as photographic records can be obtained through camera or cell phone use. The results of the study suggest that the use of RPAS can facilitate an aerial view of the accident site with considerable ease, and this view is not possible with the use of handheld cameras or smartphones. According to the investigators, RPAS has the capacity to improve the quality of investigations, and it is useful to understand the dynamics of an aeronautical accident. At places of difficult access for the investigator, such as accidents in flooded or closed forest areas, the RPAS was observed by investigators as a useful tool that can facilitate the process of air accident investigation. Furthermore, RPAS significantly reduces the time to obtain aerial images, as well as the cost for this acquisition. 
- P2: accident investigators consider RPAS a complex and fragile device and avoid its use for this reason. The investigators considered the RPAS a useful tool for the investigation of an aircraft accident and it has easy use. Investigators who never had contact with the equipment claimed it is easy to learn how to pilot the RPAS. However, the use of RPAS should be assessed based on the crash location site and on how will the investigator get to the accident location. The transport of RPAS on commercial aircraft was observed as a limiting factor in the use of RPAS due to the reduced available space in the bin.

As a suggestion for future papers, we recommend conducting this research in investigative organizations that were not included in this study (SERIPA 4 and CENIPA). Furthermore, we propose a longitudinal survey of the subject, with the aim of reaching new conclusions from the experimental maturity of investigators, noting a greater number of appliance uses. Studies in investigation organizations of aeronautical accidents in other countries may help in the development of a body of scientific knowledge in RPAS use. We believe that the acceptance of a RPAS model for aircraft accidents can be developed based on the arguments of this study. Thus, a quantitative study can be developed according to constructs and variables defined at this paper.

Although we have followed methodological procedures required for a scientific study, limitations can be considered. TAM, in general, were developed for quantitative studies, and their application in qualitative works should be carried out with great care. Our study does not allow generalizations to be made for the whole SIPAER or even for the aeronautical accident investigation agencies worldwide. The short time of experience of aeronautical accident investigators with RPAS may have influenced the perceived utility and ease of use of RPAS. In addition, the occasion of the interviews - during or a few moments after the RPAS training period at SERIPA - may have contributed to a better perception of the equipment.

\section{AUTHOR'S CONTRIBUTION}

Conceptualization: Maria HDM, Frogeri RF and Piurcosky FP; Data curation: Maria HDM, Frogeri RF, Piurcosky FP and Prado LA; Formal analysis: Maria HDM, Frogeri RF and Piurcosky FP; Funding acquisition: Frogeri RF; Investigation: Maria HDM; Methodology: Maria HDM, Frogeri RF and Piurcosky FP; Project administration: Maria HDM, Frogeri RF; Resources: Maria HDM and Frogeri RF; Supervision: Maria, HDM and Frogeri RF; Validation: Maria HDM, Frogeri RF, Piurcosky FP and Prado LA; Visualization: Maria HDM and Prado LA; Writing - original draft preparation: Maria HDM and Prado LA; Writing - review \& editing: Maria HDM and Prado LA.

\section{DATA AVAILABILITY STATEMENT}

The data regarding Interview Script and Demographic Data of the respondents that support the findings of this study are openly available in Mendeley Data at http://dx.doi.org/10.17632/8vd972pdhy.1

The data regarding Interviewees are not publicly available due restrictions that could compromise the privacy of research participants.

\section{FUNDING}

Research Department of the UNIS Educational Group.

\section{ACKNOWLEDGMENTS}

To the Research Department of the UNIS Educational Group, Brazilian Air Force. 


\section{REFERENCES}

Alfaro RAF (2015) Os veículos aéreos não tripulados na PSP: visão estruturante e aplicabilidade operacional (Master’s Thesis). Lisboa: Instituto Superior de Ciências Policiais e Segurança Interna. Retrieved from <https://comum.rcaap.pt/ handle/10400.26/15426>. Accessed on Oct. 02, 2018. https://doi.org/10.11606/t.55.2019.tde-25032019-100534

Agência Nacional de Aviação Civil - ANAC (2016) Organização da Aviação Civil Internacional (OACI). O Brasil na Organização da Aviação Civil Internacional (OACI). Brasília. Retrieved from <http://www.anac.gov.br/A_Anac/ internacional/organismos-internacionais/organizacao-da-aviacao-civil-internacional-oaci>. Accessed on Sept. $17,2018$. https://doi.org/10.26512/2002.07.tcc.1718

Agência Nacional de Aviação Civil - ANAC (2017) Requisitos Gerais para Aeronaves não Tripuladas de uso Civil. RBAC $\mathrm{n}^{\circ}$ 94E EMD00. Brasília. Retrieved from: <http://www.anac.gov.br/assuntos/legislacao/legislacao-1/rbha-e-rbac/rbac/ rbac-e-94-emd-00/@@display-file/arquivo_norma/RBACE94EMD00.pdf>. Accessed on May 14, 2018. https://doi. org/10.5220/0005122105000509

Bardin L (2016) Análise de conteúdo. São Paulo: Edições 70.

Brasil (2016) Ministério da Defesa. Comando da Aeronáutica. Edital de Pregão Eletrônico nº 087/GAP-DF/2016. Brasília. Retrieved from <http://comprasnet.gov.br/acesso.asp?url=/livre/Pregao/ata0.asp>. Accessed on Sept. 20, 2018.

Brasil (1946) Decreto n. 21.713, de 27 de ago. de 1946. Promulga a Convenção sobre Aviação Civil Internacional, concluída em Chicago a 7 de dezembro de 1944 e firmado pelo Brasil, em Washington, a 29 de maio de 1945. Rio de Janeiro. Retrieved from <http://www.planalto.gov.br/ccivil_03/decreto/1930-1949/D21713.htm>. Accessed on Aug. 09, 2018. https://doi. org/10.1590/2237-101x02004007

Cervo AL, Bevian PA, Silva R (2006) Metodologia científica. 6 ed. São Paulo: Pearson.

Clothier RA, Greer DA, Greer DG, Mehta AM (2015) Risk perception and the public acceptance of drones. Risk Analysis 35(6):1167-1183. https://doi.org/10.1111/risa.12330

Comitre AU, Balcewicz LC (2018) Estudo sobre a implementação de um sistema de entregas de pizzas com a utilização de RPAS. Braz J Technology 1(1):15-34. Retrieved from <https://www.brazilianjournals.com/index.php/BJT/article/ view/335/54>. Accessed on May 13, 2018.

Constantinescu SG, Nedelcut F (2011) UAV systems in support of law enforcement forces. International Conference of Scientific Paper, AFASES, p. 1-9. Air Force Academy Romania: Galati University. Retrieved from: <https://bit.ly/2DymYcb>. Accessed on May 13, 2018.

Davis F (1989) Perceived usefulness, perceived ease of use, and user acceptance of information technology. MIS Quarterly 13(3):319-340. https://doi.org/10.1016/S0305-0483(98)00028-0

Davis F, Bagozzi R, Warshaw P (1989) User acceptance of computer technology: a comparison of two theoretical models. Management Science 35(8):982-1003. https://doi.org/10.1287/mnsc.35.8.982

Davis FD, Venkatesh V (1996) A model of the antecedents of perceived ease of use: Development and test. Decision Sci 27(3):451-481. https://doi.org/10.1111/j.1540-5915.1996.tb01822.x

Departamento de Controle do Espaço Aéreo - DCEA (2016) Sistemas de aeronaves remotamente pilotadas e o acesso ao espaço aéreo brasileiro. ICA 100-40. Rio de Janeiro. Retrieved from <https://publicacoes.decea.gov.br/?i=publicacao\&id=4510>. Accessed on May 14, 2018. https://doi.org/10.11606/d.3.2006.tde-22042007-233948 
Fishbein M, Ajzen I (1977) Belief, attitude, intention, and behavior: An introduction to theory and research. Retrieved from: <https://www.jstor.org/stable/40237022>. Accessed on Oct. 14, 2018.

Gil, A. C. (2008). Métodos e técnicas de Pesquisa Social (6th ed.). São Paulo: Atlas S.A.

Gomez L, Parra J, Velez J, Avellaneda J, Ospina L (2017) Proposal to use UAS in the investigation of aviation accidents in Colombia. San Buenaventura University. IEEE/AIAA 36th Digital Avionics Systems Conference. St Petersburg, USA. https:// doi.org/10.1109/DASC.2017.8102149

Hawkins S (2016) Using a drone and photogrammetry software to create orthomosaic images and 3D models of aircraft accident. ISASI 2016 Seminar. Reykjavik, Iceland. Retrieved from <https://www.isasi.org/Documents/Hawkins\%20-\%20 Using\%20a\%20drone\%20and\%20photogrammetry\%20software\%20V4\%20(PAPER).pdf> Accessed on Oct. 2, 2018.

Hora GS, Menezes JS, Júnior GP, Neto AM (2018) Avaliação de ferramentas de mineração de dados: uma abordagem com o modelo TAM. Interfaces Científicas - Exatas e Tecnológicas 2(3):109-121. https://doi.org/10.17564/2359-4942.2018v2n3p109-121

Kurtz R, Soares TD, Ferreira JB, Freitas AS, da Silva JF (2015) Fatores de impacto na atitude e na intenção de uso do m-learning: um teste empírico. Rev Eletrônica Adm 21(1). https://doi.org/10.1590/1413-2311.0542013.46305

Nunes TJ (2017) Aplicação da tecnologia através de drones no Corpo de Bombeiros Militar de Santa Catarina. Universidade Federal de Santa Catarina. Araranguá. Retrieved from <https://repositorio.ufsc.br/handle/123456789/181442> Accessed on Oct. 02, 2018. https://doi.org/10.20872/24478407/regmpe.v2n3p125-145

Lidynia C, Philipsen R, Ziefle M (2016) Droning on about drones - acceptance of and perceived barriers to drones in civil usage contexts. Advances in human factors in robots and unmanned systems. AHFE 2016 International Conference on Human Factors in Robots and Unmanned Systems, p. 317-329. Orlando, EUA. https://doi.org/10.1007/978-3-319-41959-6_26

Macsween-George SL (2003) A public opinion survey - unmanned aerial vehicles for cargo, commercial, and passenger transportation. 2nd AIAA “Unmanned Unlimited” Conference and Workshop \& Exhibit, San Diego, California, September 15-18. https://doi.org/10.2514/6.2003-6519

Oldacre R (2016) Empirical examination of user acceptance of enterprise resource planning systems in the United States (Doctoral Dissertation). Minneapolis: Walden University. Retrieved from < https://scholarworks.waldenu.edu/cgi/ viewcontent.cgi article=3142\&context=dissertations $>$. Accessed on May 5, 2018.

Rangel SC (2018) Análise e classificação de fatores humanos, operacionais e materiais aplicado na investigação de acidente em operações com drones no uso civil e comercial. Braz J Technology 1(1):2-14. Retrieved from <http://brjd.com.br/index. php/BJT/article/view/331> Accessed on Oct. 02, 2018.

Rondan-Cataluña FJ, Arenas-Gaitán J, Ramírez-Correa PE (2015) A comparison of the different versions of popular technology acceptance models a non-linear perspective. Kybernetes 44(5):788-805. https://doi. org/10.1108/k-09-2014-0184

Silveira DT, Códova FP (2009) A pesquisa científica. In Métodos de Pesquisa (pp. 31-42). Porto Alegre, RS: Editora de UFRGS.

Walliman N (2018) Research methods: the basics. London: Routledge. https://doi.org/10.4324/978131552901

Venkatesh V (2000) Determinants of perceived ease of use: integrating control, intrinsic motivation, acceptance model. Information Systems Research 11(4):342-365. https://doi.org/10.1287/isre.11.4.342.11872

Venkatesh V, Bala H (2008) Technology Acceptance Model 3 and a Research Agenda on Interventions. Decision Sciences Institute 39(2):273-315. https://doi.org/10.1111/j.1540-5915.2008.00192.x 
Venkatesh V, Morris MG, Davis GB, Davis FD (2003) User acceptance of information technology: toward a unified view. MIS Quarterly 27(3):425-478. https://doi.org/10.2307/30036540

Venkatesh V, Thong J, Xu X (2012) Consumer acceptance and user of information technology: Extending the unified theory of acceptance and use of technology. MIS Quarterly, 36(1):157-178. https://doi.org/10.2307/41410412 